\title{
Denationalization and Discrimination ${ }^{1}$
}

\author{
Matthew J. Gibney
}

\section{Biographical Note}

Matthew J. Gibney is Elizabeth Colson Professor of Politics and Forced Migration at the University Oxford and Director of the Refugee Studies Centre. He specialises in the political and ethical issues raised by refugees, citizenship, and migration control. He is the author of The Ethics and Politics of Asylum (2004), Globalizing Rights (2003), which has been translated into Italian and Spanish, The Normative, Historical and Political Contours of Deportation (2013) (edited with Bridget Anderson and Emanuela Paoletti), (with Randall Hansen) Immigration and Asylum (2005), a three volume encyclopedia, and many articles in scholarly journals. He is currently completing a book entitled Denationalization and the Liberal State.

\begin{abstract}
In this piece I consider the relationship between denationalization and discrimination. Denationalization, the involuntary removal of citizenship or nationality by the state, has a dark history, reflected in the Nazi use of the power. Yet before 1945, many liberal democratic states also practiced citizenship-stripping, in ways informed by considerations of gender, race, national origin, and mode of citizenship acquisition. As denationalization is currently making

\footnotetext{
${ }^{1}$ I would like to thank Antje Ellermann for organising the workshop at which this paper was presented. She, along with Sarah Song, the other participants, and the journal's reviewers provided extremely helpful comments on this piece.
} 
a revival across a range of liberal democratic states as a way of responding to "home grown" terrorists, a question emerges: Do recent denationalization provisions manage to break free of this discriminatory past? Here, I use a discussion of denationalization's history and examination of the UK as the basis for a critical assessment of the power's contemporary incarnations. I find that contemporary denationalization power is still a powerful tracer of groups within the polity who, despite holding formal citizenship, are viewed as foreign.

Over the last decade, new laws allowing individuals, particularly those involved in terrorism, to be denationalized have emerged across a number of Western states (Macklin 2015; Gibney 2013a; Mantu 2015). In other states, provisions for citizenship revocation have been debated. Unveiling new denationalization proposals in 2014, Canada's Citizenship and Immigration Minister, Chris Alexander, stated: "Citizenship is not a right; it is a privilege" (CBC News, Sept 25, 2015). When the British Prime Minister, Theresa May, was Home Secretary, between 2010 and 2016, she removed the citizenship of around 30 UK nationals on grounds that doing so was "conducive to the public good". Soon after becoming president-elect, President Trump tweeted, "Nobody should be allowed to burn the American flag - if they do, there must be consequences - perhaps loss of citizenship" (New York Times, Nov 29, 2016).

Denationalization power is controversial from a liberal perspective. The revocation of citizenship is an extreme act of state, one analogous to the death penalty. While capital punishment involves the physical death of one of its members, denationalization involves, in principle, the individual's civic death, the severing of the ties of responsibility between the state and its citizen. Denationalization, moreover, has a dark history, reflecting, in particular, the widespread use of the power by the Nazis in their campaigns of racial exclusion and extermination of the Jews and other minority groups (Arendt 1951). 
States, like the US, Canada, Australia and the UK, are implicated in this dark history. Before 1945 in these countries explicitly discriminatory laws were in place, making some citizens vulnerable to denationalization because of their gender, race, national origin, or the way they had acquired citizenship. Denationalization laws were also enforced in discriminatory ways, reflecting informal social and political understandings of the subordinate standing of some ethnic and racial groups. Denationalization's history offers powerful insights into the way that citizenship in liberal states has been hierarchical in law and in practice (cf. Ellermann, this issue).

Have recent denationalization provisions manage to break free of this discriminatory past? I argue that they have not. Denationalization's proponents have long presented the power as one that simply responds to certain unacceptable acts. But what has constituted an act worthy of denationalization has long been profoundly shaped by the status or background of the person who undertook it. That dubious relationship lives on today in the way that denationalization is only lawfully allowed for certain categories of citizen (i.e., the naturalised and dual nationals) and in the overwhelming focus in implementation of the power on citizens with backgrounds from Muslim-majority countries.

In this article, I will use a discussion of denationalization's problematical history to launch a critical assessment of the power's contemporary incarnations. My discussion is divided into three parts. First, I attempt to define denationalization and to distinguish the power from the historical practice of banishment. Second, I consider denationalization in historical context, differentiating between different reasons states have resorted to the practice. In section III, I focus upon the experience of Britain to assess contemporary denationalization power, 
scrutinizing two possible locations for discrimination: the lawitself, and in the realm of enforcement.

\section{Understanding and Specifying Denationalization}

In simple terms, denationalization is the non-consensual withdrawal of nationality from an individual by her own state. The power transforms the individual into a non-citizen in the law, thus putting an end to the special responsibilities and entitlements that result from citizenship or nationality.

Denationalization involves non-consensual nationality loss. In most states it is possible to give up nationality voluntarily but this individual-initiated act is, in law, distinct. This difference may, however, be considerably less clear in practice. Furthermore, the term denationalization emphasises the individual's loss of nationality; that is, the legal recognition of her as a national of a particular state. However, the same power is often referred to in terms of citizenship through terms like "revocation" or "deprivation" of citizenship.

States have used denationalization primarily because they wish to cut ties of legal and moral responsibility to a particular citizen (or group of its citizens) to enable their expulsion or exclusion. By transforming an individual into a non-citizen the individual concerned may lose the right to reside in the state and become vulnerable to deportation power. For example, the current aim of most recent denationalization is to banish terrorists and displacing the threat they pose to another country of nationality (Macklin 2015, 1).

Historically, denationalization has also served other purposes. During the 1940s, the Nazi regime was careful to make sure that "Jews and gypsies were completely denationalized" before they were deported to the extermination camps (Agamben 1995,117) The Nazis wanted legally to appropriate their financial assets (Dean 2002). By contrast, denationalization has 
sometimes been used simply to shame individuals by publicly degrading their status. Under a US law of 1940, members of the military dishonourably discharged for desertion during War could be denationalized (Alienikoff 1986).

One way of bringing the distinctive character of denationalization into view is by comparing it to the punishment of banishment. Banishment was a specific legal penalty for offenders that entailed expulsion from the community (the city, the province, or the state) that was ubiquitous in medieval and early modern Europe (Spierenburg, 1997). Banishment was a unilateral act of rejection. The individual lost all rights to membership because of acts deemed unworthy of a member and was consequently ordered to quit the community's territorial boundaries. Banishment's primary ideological and legal function was to transform a member into an outcast, someone ostracized from society, forbidden to return for a specific period or forever.

Denationalization, which becomes common on at the beginning of the $20^{\text {th }}$ century, also involves membership loss, but it operates in a distinctly different ideological and institutional context. The ideology of nationalism, elucidating an ostensibly natural link between a particular people and a society, makes it more difficult for a state simply to absolve itself of responsibility for a particular citizen. This difficulty is reinforced by the development of an international system that exhaustively divides up the world into sovereign membership units. As one international lawyer noted in 1927, "it is no longer possible to send undesirables abroad. Slops may be thrown out of the window of a settler's hut on a prairie; in a town such practice is inadmissible" (Fischer-Williams 1927, 57). For denationalization to be legitimate in a world of states, the expelling community cannot simply characterise the former citizen as an outcast. The individual must be portrayed as someone who rightly belongs in another state; the individual must be turned into a foreigner. 


\section{Justifying Denationalization}

How was this act of transforming the citizen into a foreigner justified? Drawing upon the historical experiences of the US, the UK, Australia and Canada, three major ways-- analytically distinct but sometimes practically overlapping--are evident. States have claimed that the citizen in question was: never truly a lawful citizen; owed true allegiance elsewhere; and was an active enemy, typically by doing the bidding of some foreign power. These processes of justification and construction have often mapped onto to invidious hierarchies of citizenship based on race, gender, ethnicity and religion.

\section{Never a lawful citizen}

In most Western states, denationalization laws first emerged less to root out the disloyal or the dangerous than to address a more mundane concern: to undo grants of naturalization falsely obtained through fraud or misrepresentation. In the US, denationalization came legally into being in 1906 with an act that gave federal attorneys power to bring suit to cancel a "certificate of citizenship on the ground of fraud or on the ground that such a certificate was illegally procured." (Weil 2012, 19). This new federal power was primarily aimed at stopping electoral corruption enabled by fraudulent naturalization certificates to increase votes (Weil 2012).

In 1914, the British government sought similar powers in the British Nationality and Status of Aliens Act. This power was enacted amidst long running concerns that some individuals were naturalizing in the UK without possessing any real intention to reside in the country, leaving soon after citizenship was granted.

The power to revoke citizenship fraudulently acquired was a modest claim. Yet the power could be manipulated in ways that promoted discrimination. In the US, a certificate could be withdrawn if an individual failed to meet any of the stated criteria for naturalization, including being ""racially" eligible", that is, Negro or white; able to speak English; possessing a "good 
moral character"; and being committed to the "principles of the Constitution" (Roche 1960). Furthermore, these US laws were enacted at a time of growing concern about immigration. Between the 1880 s and the early 1900s, increasing numbers of migrants to the US began to arrive from southeastern Europe instead of traditional source countries in northwestern Europe (King 2009). Princeton University's President publicly lamented how the "sturdy stocks" of immigrants from Europe's north were being overtaken "by multitudes of men of the lowest class from the South of Italy and men of the meaner sort of Hungary and Poland" (King 2009, 51). When the 1907 Act was debated in Congress, stories of electoral corruption were luridly illustrated with examples of fake naturalization papers being sold on to "Italians" and "other foreigners".

Within a decade, the US was at war with Germany and the provisions on fraud were being used to hound citizens of foreign background who demurred from unerring support for the US. In a highly trumpeted speech in December 1915, Woodrow Wilson proclaimed as America's biggest threat not events in Europe but those naturalised citizens who "have poured the poison of disloyalty into the arteries of our national life" (Wilson 1915).

In this febrile environment, courts, encouraged by federal authorities, used an elastic interpretation of laws on fraudulent acquisition to denaturalize. One US citizen for 36 years, Frederick Wusterbath, was brought before a court because he refused to buy Liberty Bonds, apparently because he didn't wish to hurt Germany, his country of origin. (New York Times, 14 May 1918).

Wusterbath lost his citizenship. A federal court found that he had possessed a "mental reservation" at the time of naturalisation that prevented him from fully committing to the US. The court reasoned: "If, ... after thirty-six years, he now recognizes an allegiance to the sovereignty of his origin superior to allegiance to this country, it seems to me ... that he took 
the oath with a mental reservation to the country of his birth" (New York Times, May 14, 1918).

In the UK, hostility to Germans during WWI was just as powerful, leading also to questions about citizenship fraud. During the War, a coterie of parliamentarians called for new legislation to review the naturalisation granted to all individuals who originated from "enemy countries". It is not, one conservative MP noted, open German subjects we should fear but "those...living in this country who have recently... become naturalised British subjects". It is evident that "if a man came to this country with mischievous intentions, he would take the precaution to become a naturalised Britisher" (HC 3 March 1915, c.849).

Many politicians argued that the naturalisation certificates of citizens originally from enemy countries were invalid because they were acquired for the wrong reasons. According to Henry Dalziel, "Germans who became naturalized since the beginning of the war did it practically for business reasons, for their own reasons, under duress." (HC 11 July 1918, c 541). When the Liberal government presented a Bill to Parliament with denaturalization provisions in 1918, he Home Secretary defended the new law because "a man who is naturalized here really gives a statement of good character, a promise to be of good behaviour, a promise of loyalty, and if these promises are broken it is only fair that the state should have the right to revoke a privilege" (HC 12 July 1918, c.624). By 1921, the certificates of those naturalized since the beginning of the war under the Act led to 18 revocations out of the 148 reviewed (Husbands 2007, 509).

\section{Conflict of Allegiance}

Another justification for denationalization involved the desire to avoid "conflicts of allegiance". Conflicts brought about by situations of dual nationality or through continued residence in an individual's country of origin after naturalization were deemed problematical because they risked embroiling the state in international disputes over matters of military 
duties, taxation, etc. and divided the individual's duties. As Spiro notes, "Dual nationals represented instability in a world in which the downside risks of instability were serious, in an era in which there were no brake triggers on the way to war" (Spiro 2010, 113).

In the US, the desire to avoid such complications was evident from the 1906 Act. Acts in 1906 and 1907 included provisions for citizenship loss for naturalised citizens who lived overseas for more than five years. These were designed to prevent citizens abroad with few connections to the country, taking up the time of US consular officials. The officials, Congress was told, worried that "serious international troubles" might be stirred up by the misuse of provisions enabling American nationals in the Ottoman Empire to be tried and punished for locally committed offences solely by US consular officials. There was a whiff of racism in these concerns, as they were primarily directed at US citizens of Turkish descent, at a time of hostility to those of this origin.

In the UK, the rumour that some Germans had dual nationality served as one reason for "breaking the naturalization contract" during WWI. This concern had long simmered because of a German citizenship law of 1913, enabling those of German origin naturalizing to keep their German citizenship under certain limited circumstances (HC Deb 12 July 1918, cc 62267). This provision became a ground for impugning the commitment all naturalized Germans. Henry Dalziel argued that Germans naturalized since 1914 "were not really entitled to become naturalized, and, therefore, there is no breach in faith in reviewing ...their certificates" (HC Deb 11 July 1918, c.541).

An example of the crossover between group discrimination and concerns about multiple allegiance involved women who married foreigners. In an attempt to bring the kind of clarity desired by US government officials, the 1907 Act, brought US laws into line with a British law 
which mandated citizenship loss when a woman married a foreigner. It was assumed that the woman would attain the nationality of her husband.

That a woman's citizenship was treated so lightly reflected the view that "a wife owed her primary political allegiance to her husband rather than to her nation" (Cott 1998, 1462). The assumption was that a woman would follow her husband to his country of nationality. This treatment also reflected xenophobic concerns. According to Smith, the provisions in the Act depriving women of citizenship led to it being dubbed the "Gigolo Act" because marriage was seen as a route by which "conniving alien men married American women simply to get a foothold in the US" (Smith 1999, 457). Effectively, the Act risked pushing women into statelessness so as to avoid introducing "foreign elements into the body politic" (Cott 1998, 1461).

These provisions were not uncontroversial. In 1913, Ethel McKenzie went to register to vote in California but was refused permission to do so because her husband was a British citizen and she had lost citizenship upon marriage. McKenzie contested the decision in court arguing that her citizenship "was ...a right, privilege, and immunity which could not be taken away from her except as a punishment for crime or by her voluntary expatriation" (Mackenzie v. Hare, 239 U.S. 299 (1915)). 
In the Supreme Court, the loss of her citizenship was adjudged constitutional: "the identity of husband and wife is an ancient principle of our jurisprudence... and this relation and unity may make it of public concern in many instances to merge their identity, and give dominance to the husband". Congress's desire for a singular national identity for a husband and wife is "no arbitrary exercise of government" but has the aim of not bringing "the government into [international] embarrassments, and... controversies" (Mackenzie v.Hare, 239 U.S. 299 (1915)). On the question of whether such an act could be considered a voluntary expatriation, the Court argued that marriage "is as voluntary and distinctive as expatriation, and its consequence must be considered as elected."

What obscured the idea that women's citizenship was of lesser value was the 1907 Act's focus on expatriation. The idea that one could renounce one's citizenship had long been an issue. Against the traditional British view that a citizen's obligation of allegiance was perpetual, Congress had powerfully affirmed in 1868 that the right of self-expatriation was a basic human right (Smith 1997, 313).

In this formulation expatriation was an individual right that limited state power. In the 1907 Act, however, expatriation was reinterpreted to empower the state. The government was to judge when an individual had transferred citizenship. The use of expatriation, like the concept of fraud in the 1907 Act, created the fiction that the state was not acting affirmatively to revoke citizenship.

\section{Enemies of the state}

Denationalization due to a conflict of allegiance did not normally involve an act of condemnation. Women who married foreigners were simply unable to give undivided commitment. But a third ground for denationalization, when individuals were deemed "disloyal" or "treacherous", did involve public censure. This type of action was typically used 
to deal with an "enemy of the state" during war or an individual who seen as promoting the interests of a foreign power. In the UK, in the 1950s and 1960s, several Soviet spies were denationalized and deported to the Soviet Union for treachery under 1918 legislation that specifically enumerated treachery as grounds for citizenship loss. This legislation led to the denaturalisation of dozens of Germans at the end of WWII for actions that included "trading with the enemy" (Gibney 2013a).

In Australia during WWI, even the merest hint of disloyalty could serve as a basis for denationalization if one was a member of an unpopular group. A 1917 Act allowed the Governor-General to remove citizenship from an individual when "it is desirable for any reason that a certificate of naturalization should be revoked". This provision was challenged in the High Court in 1920 by a naturalized citizen of German origin, Frederick Meyer, who had been interned by the Australian government during the WWI. Upon his release, censors continued to surveil his mail and after they found an obscure wish to extract revenge against the Prime Minister, Meyer received a one sentence letter telling him that his naturalization had been revoked (Nicholls 2007, 51). His appeal failed when the High Court found that "the revocation of the certificate is entirely in the discretion of the Governor, and his decision cannot, nor can his reasons for it, be canvassed in any Court of law" (HC Australia, June 4 1920).

The examples of denationalization discussed above involved naturalized citizens. How did governments proceed when they wanted to expunge the citizenship of the native born? An illustration is the case of the US and Canada's treatment of interned Japanese-Americans and Japanese Canadians during WWII.

In both of these countries, governments and political leaders went to great efforts to present the internees as having willingly expatriated themselves to facilitate their expulsion. As WWII 
drew to a close and the expulsion of Japanese internees became a realistic possibility, the US government proposed to survey the internees to identify those prepared to renounce their citizenship and return to Japan. Federal authorities estimated that between one and four thousand internees would be willing to sign a renunciation oath.

This proposal however required new legislation and a Denationalization Bill was introduced to Congress in 1944. The Bill aimed "to permit certain citizens to renounce their American citizenship and permit such renunciation while the person is within the United States" (HR. 16 Feb 1944, 1778). Endorsing the Bill as a way of ridding the country of enemy "Japanese", Congressman Sabath (D-Ill) proclaimed, "Of course, I myself would be most happy if we could get rid of all of them as quickly and as speedily as possible" (HR. 16 Feb 1944, 1778). Notwithstanding, the Bill was immediately attacked by anti-Japanese congressmen from the western states of California, Washington and Oregon. These congressmen complained the need for an explicit written renunciation was unnecessary. Rep. Leroy Johnson claimed that any Japanese-American who had expressed allegiance to Japan "orally or written" at any time since the Selective Service Law came into force in September 1940 had "in fact renounce[d] his citizenship”. (HR, 16 Feb. 1994, 1779)

In response to an amendment, a more pragmatic group of Congressmen argued that broadening the scope of the Bill would be unconstitutional. As one objected: "under the Constitution a man born here of any race is an American citizen. What are we going to do with him in court?.. you cannot take away his birthright, and that is exactly what my colleagues from California want to do" (HR. 16 Feb 1944, 1784-5). Other congressmen worried that any such provision would have implications well beyond the interned Japanese; it could make every American's citizenship insecure. 
Of course, the practical gap between the two groups was lessened by the fact that any explicit renunciation was exercised under coercive conditions because the internees had endured years of rejection at the hands of the US government. The inequity of surveying only citizens of Japanese origin formed a part of neither side's considerations. Participants on all sides commonly premised their statements with testimonies of how much they despised all Japanese.

As we have seen, involuntary expatriation was hardly alien to the American tradition. The situation of women - which had by the 1940s been largely reversed - and laws against naturalised citizens living overseas both dubiously relied on indirect actions to signal agreement to expatriation.

Ultimately, the Bill's supporters managed to defeat the amendment and move the Act as originally proposed. The Act passed in July 1944 and by October a new procedure for renunciation had been put in place. The procedure required an internee to make a written request for renunciation; a hearing would then follow. Between March and May 1945, some 5049 applications for renunciation were approved (Ngai 2004, 191). With the end of the war that August, those American citizens of Japanese descent still interned were able to leave but those who had renounced citizenship or requested return to Japan stayed interned while the government arranged deportation.

A similar process unfolded in Canada. The Canadian government used a questionnaire to survey the willingness of Japanese internees to be repatriated. Some 6,884 adults had agreed to repatriation by August 1945 (Sunahara 1981, 109), a figure that, when dependent children were added, represented some 43 percent of all Japanese-Canadians. Alienation after years of internment by Canadian authorities, the uncertainties of resettlement, and a belief that they could change their mind in future, explained this choice. However, the unexpectedly quick end 
to the Pacific War in 1945 led most internees, now facing the imminent prospect of return to a devastated Japan, to rethink their decision (Sunahara 1981, 109).

In response, the government pursued a number of legal avenues enabled by war time emergency powers to enforce deportation. These powers, effectively enabling Canada to deport its own citizens, were contested by civil society groups in the latter days of the war, but were upheld (to varying degrees) by the Supreme Court and by the Privy Council in London. Only when the deportations became politically untenable because public attitudes against JapaneseCanadians softened after the War, did the government finally abandon the policy, though some 4000 people ultimately left to a devastated Japan under coercive conditions (Sunahara 1981, 126).

This brief overview of the history of denationalization shows how the power targetted a range of ascriptively-defined social groups. Denationalization's proponents presented the power as a response to commission of certain acts. But what constituted an act warranting denationalization was profoundly shaped by who undertook it: a disloyal utterance mattered when it was spoken by someone of German origin during WWI; marriage to a foreigner became significant when it was by a woman; living overseas constituted a failure of citizenship when it was undertaken by a naturalised citizen.

This process of "foreigner-making" was not disconnected from liberal norms. As we have seen, denationalization might have been motivated by nationalist accounts of belonging but it was legitimated by ideas of the contract and freedom of association. Those subject to denationalization had either failed to live up to their end of the "citizenship bargain" or had, through their actions, exercised their right to expatriate themselves. Denationalization in the 
first half of the twentieth century is characterised by an unholy alliance between exclusivist national ideals of membership and accounts of the state as a mutual and voluntary association.

\section{Denationalization in Retreat}

For all the frantic denationalization activity during WWII, within thirty years, denationalization had largely disappeared across Western states. In many states, the power to denationalize had been formally excised from the law; in others, the power was almost never used. What happened?

Part of the answer lies in the fact that the unholy alliance that sustained denationalization in the pre-War period was undermined both by the actions of avowedly illiberal states, and by WWII. The use of mass denationalization by the Soviets in the 1920s and the overtly racist citizenship practices of the Nazis and the Axis countries in the 1930s and 1940s, brought denationalisation into disrepute. The Nazi and Soviet experiences linked the practice with totalitarian governance. Writing in the war's aftermath, Hannah Arendt stated that one could measure the degree to which tyranny had entered a state by the number of denationalisations it carried out $(1951,278)$.

Arendt's observation coincided with concerted attempts to make individual rights central to international law. A fragile but growing consensus was emerging amongst European states, North America and South America that the limits of state prerogatives in realm of nationality needed to be clearly clarified if the mass denationalizations of 1920s, 1930s and 1940s were to be avoided.

A significant early example of such movement was the Universal Declaration of Human Rights in 1948. Article 15 stated that "everyone has the right to a nationality" and "that no 
one shall be arbitrarily deprived of his nationality". The UDHR was a key moment international law's change from an "order centred" conceptualisation of nationality recognising solely the interests of states to one concerned with "individual interests in nationality" (Spiro 2011, 710). However, as a declaration rather than binding law, the UDHR represented a "discursive shift" rather than a change in "actionable norms" $(2011,710)$.

International rules on statelessness offered another way to constrain revocation powers. The 1961 Convention on the Reduction of Statelessness specifically dealt with deprivation of citizenship, prohibiting denaturalisation when it was carried out for reasons of race, religion, or political orientation. Furthermore, the Convention largely limited lawful denationalization to circumstances when an individual had acquired another nationality. Here, the problem of “actionable norms" raised its head again, as few countries signed the Convention.

Nonetheless, if action at the level of international politics tended to be confined to desirable statements, more profound changes were afoot within Western states. After 1945, the practice of denationalisation fell into disrepute. The rupturing experience of WWII and the horror of the Holocaust ushered into prominence what Triadofilopolis has called "a more universalist, and anti-racist liberalism" (2011). The norms of this liberalism stood in tension with denationalization provisions in ways that created pressure for the power to be curtailed.

Diverse actors including judiciaries, political parties, and migrant and human rights pressure groups, oversaw the development of new constraints on denationalization. Norms against the creation of statelessness, the arbitrary exercise of power, and unequal standards in citizenship became evident (Gibney 2013b.). In, Canada and Australia denationalization virtually disappeared from the statute books. In the US, involuntary loss of citizenship was essentially made unconstitutional through a series of decisions (Weil 2012). In Canada, parliament restricted the state's right to revoke citizenship solely to cases of fraud and misrepresentation 
in 1974. In the UK and France, the power became virtually redundant through disuse by the executive. Between 1945 and 2002, for example, the UK stripped citizenship only ten times.

\section{Contemporary Denationalization and Discrimination}

Denationalization's retreat has proven short-lived. The power's re-emergence across Western countries can largely be dated from the Al Qaeda terrorist attacks of September 11, 2001. In the UK, September 11 attacks and the subsequent July 7, 2005 tube and bus bombings in London have led to new legislation. In the US, a steady stream of politicians have proposed measures to strip citizenship from those who join foreign terrorist organizations ostensibly at war with the US over the two decades. While these proposals have foundered on the Constitution, new powers have emerged in Canada, Australia, the Netherlands, Austria and Belgium to deal with jihadis, particularly since the Syrian war began in 2011.

Paradoxically, denationalization's revival has been both widespread and modest. Many countries have introduced new laws but have tended to use their new powers relatively sparingly. In Britain, the country with those most wide-ranging citizenship stripping provisions, only 5 to 6 people have lost their citizenship annually in the last decade (House of Commons Briefing Paper, 2017).

Moreover, new manifestations of the power are tightly constrained by liberal principles. This is evident in a number of ways. First, in many countries, denationalization requires a criminal conviction (France, Canada, Belgium) or the exercise of executive authority is overseen by a process of judicial review (the UK, Australia) (Gibney 2013a; Mantu 2015). Second, no liberal state now revokes citizenship from women after marriage and laws enabling loss of citizenship for possession of dual nationality have become rare (Joppke 2010) Third, denationalization power is now almost always limited to dual nationals, reducing concerns about statelessness (Gibney 2013b; Macklin 2015b). 
Do these careful changes to denationalization mean that the power has shrugged off its discriminatory past? To answer this question we need to look in two directions. First, we need to consider the construction of the law, whether it formally discriminates. Second, we need consider how the law is enforced in practice, whether the power is exercised in unjustified and discriminatory ways. Given limits of space, I will take up these issues through the example of Britain, a country that has led the development of denationalization laws in the period since 2001.

\section{Discrimination in the Law}

Let us begin with discrimination as a formal legal construction. The UK's law makes provision for denationalization in two circumstances. The first, and most wide-ranging, comes from the 2006 Immigration, Asylum and Nationality Act and enables the Home Secretary to denationalize when she thinks doing so is "conducive to the public good." This power applies to dual nationals (both birthright and naturalised citizens) but can be used only if doing so does not render the individual stateless. A second provision, contained in a 2014 Immigration Act, applies only to naturalized citizens. The Home Secretary may denationalize if she considers that the individual has acted in a manner which is "seriously prejudicial to the vital interests of the United Kingdom". Under this law, an individual can be made stateless if there are "reasonable grounds" for believing the person "is able to become a national of another country."

On the face of it, these laws seem problematical. Democratic citizenship, as Lenard has noted, "is commonly understood to be egalitarian, that is, it protects an equal package of rights for all citizens" (Lenard 2016, 73). Yet these laws mandate different treatment, discriminating between citizens on the basis of how they acquired citizenship (by naturalisation/birth) and how many citizenships they hold (dual or multinationals/ mono-nationals). If a dual national 
and a single national undertake the very same act (or pose the same threat to the public good), only the dual national will lose citizenship (Gibney 2013b).

This vulnerability is of great moment for the individuals concerned. Under the 2014 Act, naturalized citizens (alone) may be made stateless, a situation that would deny them all the rights and protections of citizenship anywhere, including security of residence in the state. Under the 2016 Act, a dual national may lose citizenship, depriving them of all the rights that come with that status, including, potentially the right to live in the UK.

That said, in the democratic state, treating all citizens equally does not generally require treating them the same (Barry \& Ferracioli 2015; Gibney 2013b). Sometimes treating people equally requires different treatment, such as the provision of special services for historically disadvantaged groups. What we want to know in assessing the UK's laws is not simply whether discrimination is occurring but whether it is invidious and unjustified.

Let us consider this question first in relation to the 2014 Act. How does the British government justify the discrimination against naturalised citizens in this Act? The government's position revives the consent-based justification used during WWI. Defending the 2014 provisions relating the naturalised, the Home Secretary stated that a commitment to behaviour consistent with common British values "is encapsulated by the oath that naturalised citizens take when they attend their citizenship ceremonies" (HC Deb, 30 Jan 2014, c.1042). She believes that the naturalized warrant special treatment because they have expressly agreed to uphold "British values".

The problem with this argument, however, is that consenting to a particular form of treatment does not in and of itself justify the treatment. Some people would agree to work for very low wages, but that does not mean that we should not have minimum wage laws. Indeed, that is just why such laws are necessary (Carens 2008). Equally, a state would not be justified in 
giving naturalised citizens uniquely long prison sentences, no matter what was agreed upon taking up citizenship.

To justify treating the naturalised differently than the native born, one needs a reason that appeals to a relevant difference in these two groups' need for citizenship or in the burdens imposed by citizenship's loss (Barry \& Ferracioli 2015). In just these respects, the two groups are identical. The naturalized and the native born both face the possibility of statelessness and would lose their right to remain in Britain with all the goods that this entails. Consequently, any distinction between the two is invidious and unjustified. Indeed, the UK government acknowledged this when it eliminated a distinction between the naturalised and the native born in denationalization law in 2002 because the old provision sent a message that the naturalized hold a "second class status" (HL Debates, 9 October 2002, c.279). This change was overturned by the 2014 Act.

What about the discrimination against dual nationals in the 2006 Act? This case is more complicated because here there does appear to be a morally relevant difference in how citizens stand in relation to state power and the consequences of denationalization. If the single national loses citizenship, she loses access to any citizenship. The dual national, however, can still access another citizenship and the goods that involves (Lenard 2016; Gibney 2013b).

One argument made in defence in the picking out of dual nationals for denationalization is that having a second citizenship is a privilege, not an entitlement (Lenard 2016; Gibney 2013b). Dual nationals arguably enjoy a range of benefits unavailable to mono-nationals, including the right to reside in more than one country and to enjoy the entitlements provided by two (or more) states. Vulnerability to denationalization might be seen as a way of equalizing the status of dual nationals to other citizens rather than making it inferior. 
There are problems with this argument, however. First, if democratic states view dual nationality as conflicting with democratic equality, why have they increasingly accepted it as a legitimate practice in recent years? Furthermore, second citizenships differ greatly in the privileges they offer (compare Australia and Haiti), as they do in the duties they prescribe (some involve compulsory military service) (Lenard 2018; Macklin 2015). It is thus difficult to generalise about the advantages dual nationals enjoy over mono-nationals. Finally, even if we accept that dual nationality leads to inequality, it is not obvious that making dual nationals liable to denationalization is an appropriate way of rectifying this inequality (Lenard 2018). The playing field could be levelled, for example, by only allowing dual nationals to vote or to receive welfare benefits in the country in which they reside, without the drastic step of making citizenship less secure.

Miller has made a different argument in relation to dual nationals $(2016,266)$. He suggests that denationalization might be seen not as discriminating against dual nationals but simply as treating mono-nationals exceptionally. In assessing denationalization, Miller argues, we should begin by asking whether there are reasonable grounds for believing that some acts justify removing people from the political community. If we answer yes (as he does), we must consider whether this can be done without violating an individual's fundamental rights $(2016,268)$.

In the case of the single national, the answer is "no", because the individual would be made stateless. However, with the dual national, the answer is (typically) "yes" because their basic rights can be protected by another state. Under such circumstances, it is not unfair to denationalize dual national but not the "single national".

To illustrate the intuitive force of his position, Miller points to the way sentencing courts often taken into account the likely consequences of punishments in relation to particular individuals. Not denationalizing single nationals, he says, might be analogous to "reducing the prison 
sentence imposed for causing death by dangerous driving for someone whose special circumstances would make incarceration especially onerous", such as a parent with young children (Miller 2016, 268).

This seems a plausible analogy. Many countries have laws that involve lighter treatment for potentially vulnerable groups when a punishment would involve especially harsh consequences. In the US, individuals under the age of 18 cannot be sentenced to life imprisonment without parole. Why are these laws acceptable? One answer is that there is a background equality in these cases that legitimises the inequality in question. We all pass through stages of being young, so at a particular point in our life, we all get benefit of these provisions. By contrast, many dual nationals will never be able to benefit from provisions for single nationals because their state of origin will not release them from citizenship.

A stronger objection is that even if we concede that fair treatment sometimes justifies departing from normal rules and penalties (as in the case of the parent with young children), there is nothing exceptional about the situation of single nationals being treated leniently here. On the contrary, the vast majority of citizens in contemporary states have only one nationality. Not denationalizing citizens is thus the rule, not a departure from it. Consequently, it is dual nationals who are being subjected to special treatment, and it is especially harsh treatment. They are a minority subject to denationalization via a law that was never intended to be of general application. To single out a group in such a manner for harsh treatment is indeed invidious discrimination.

There are then powerful reasons for seeing denationalization laws that pick out the naturalised and dual nationals as discriminatory and inconsistent with principles of democratic equality. These reasons make current UK laws illegitimate but they could be addressed by applying the denationalization equally to all citizens, mono-nationals and dual nationals, the native born and 
the naturalised. However, this move may engage new ethical objections to denationalization distinct from discrimination concerns (Gibney 2013; Lenard 2018; Macklin 2015).

\section{Discrimination in Enforcement}

We now turn to the question of whether denationalization laws are enforced in a discriminatory way. The key principle here is that citizens should face denationalization based on what they have done (or are likely to do) rather than who they are, their ethnic, racial or religious background. One can add to this principle the requirement that citizens should not, for the purposes of the "public good" provision, be picked out on the basis of how they acquired citizenship, as this provision is applicable to all dual nationals.

The obvious place to start an examination of enforcement is by looking at the background of those who have actually lost citizenship. This task is tricky because UK authorities generally refuse, on national security grounds, to proffer information about particular cases. However, it is possible to piece together information from a range of sources to illustrate the profile of those involved.

Under the Labour government, which passed the 2006 legislation establishing the "conducive to the public good" standard, denationalization was used in only a handful of cases. However, in the Conservative/Liberal Democrat government's first year of office in 2010-11, no fewer than six denationalization's occurred. This was more than previous Labour governments had denationalized in the preceding nine years. The more regular use of deprivation power has continued apace in the years since. Between 2011 and 2015, the government stripped around 30 people of citizenship on the "conducive" grounds (HC Briefing Paper 2017, 5).

Who were these individuals? Generalizing from information through appeals to the Special Immigration Appeals Commission, virtually all deprivations have been of citizens originally from Muslim-majority countries. Of the nine appeals considered since 2010, the countries of 
second citizenship were respectively: Morocco, Afghanistan (2), Iraq, Pakistan, Sudan (2), Somalia, and Vietnam. The individuals were believed to have connections to Islamist groups, including the Taliban, Al Shabaab, and Al Qaeda, and Daesh. This list includes only citizens who appealed to (and whose cases have been decided by) SIAC. Nonetheless, this concentration suggests that denationalisation power is primarily used against Muslims.

This is not proof of discriminatory treatment. It might be said that the threat from Islamist extremist groups is the major terrorist threat today and it would be surprising if members of the Muslim faith were not over-represented. But there are reasons to be concerned. The amount of discretion public officials have in the realm of denationalization together with the power's historical association with the discriminatory targeting, makes it important not to accept this explanation too quickly. Indeed, the common perception that Islamist terrorism is the biggest terrorist threat facing liberal states might itself be grounded in a prejudice against Muslims (cf. Dauvergne, this issue).

In work examining UK counter-terrorism documents, Maria Norris (2016b) has argued that, despite adhering to an ostensibly impartial definition of terrorism, authorities consistently conflate terrorism and Muslim extremism, leaving little room for the actions of other groups to be qualify as terrorist. She notes the different treatment in public discourse of the Muslims who brutally killed the British soldier Lee Rigby in 2013 and the response to the murder of the MP Jo Cox by a right-wing extremist in 2016. While both fitted under the definition of terrorism only the one committed by Muslims was treated as a terrorist act. Rigby's killing fitted into a narrative of government officials and media sources that violent acts by Muslims are terrorism (Norris 2016a). Others commentators have asked why the issue of denationalization was never used in the case of members of IRA, who engaged in a long running campaign of bombings throughout the British Isles during the $20^{\text {th }}$ century (Choudhary 2017, 228). Their crimes were primarily penalised through the domestic law rather than through nationality provisions. 
Concerns about discrimination are also raised by looking at how the power is used in nonterrorist related cases. In 2012, four men were convicted for the organisation of a sex ring that exploited and raped young women in the city of Rochdale between 2008 and 2010. The convictions followed media attention on the existence of what was widely described as "Asian sex ring" in which, according to numerous commentators, Asian men preyed on vulnerable, young white women (The Express, 10 August 2017).

While the men were subsequently sentenced to prison sentences of between six and 22 years, the government's response was extraordinary. Under her powers to deprive citizenship when she deemed it "conducive to the public good", the Home Secretary notified the four that she would denationalize them for "serious and organised offences" (Ahmed 2017). Each of the four was a naturalised UK citizen, one of them had arrived in Britain as a teenager forty years before.

The government clearly considers the Rochdale deprivations as a "test case" for the principle that individuals who have "gained the benefits of British citizenship but go on to be involved in organised crime" should be denationalized and deported (Ahmed 2017). The worry is that what makes this a good test case is the Asian background of the individuals.

Why is it that an (albeit) appalling crime, like this one, is viewed as warranting deprivation when many other crimes, including those that cause greater suffering and insecurity like mass murder, are not? It is helpful to consider the British government's recent counter-terrorism strategy. This strategy has emphasised the importance of particular ethnic minority groups adhering to "British values". According to the former PM, David Cameron, ideas "hostile to basic liberal values" contribute to "a climate in which extremists can flourish"”. As Choudhary $(2017,238)$ observes:

Once radicalisation is seen as resulting from poor adherence to British values, and linked to a perceived failure of integration caused by too much multiculturalism, it becomes possible for 
the Prime Minister, in a speech tackling the threat of ISIS, to talk of the need not only to counter Islamist extremist ideology but to broaden the scope of counter-terrorism to encompass "uncomfortable debates - especially cultural ones" about female genital mutilation, forced marriages, a sharia courts and child sex abuse.

This context may explain why the Rochdale offences were viewed as warranting not just imprisonment but denationalization. The Pakistani origin of the men meant that the crimes were not simply discrete acts of individual moral turpitude; they were evidence of a deeper threat to liberal values by an ethno/cultural group considered suspect holders of British citizenship. Within this framework, the continued citizenship of the perpetrators could easily be adjudged detrimental to the "public good".

Of course, we are a way off proving that ethnic/religious origin was a determinative factor. But it is less contestable that the foreign birth of the individuals informed this response. In a statement to the media criticising an appeal by the men in 2017, the local MP, Simon Danczuk (Lab), stated that the men should not be allowed "to languish in British prisons instead of ones in their home countries". He went on: "we welcome many people coming to the UK to contribute, but if they break the law they should lose their right to live here...Foreign-born criminals should not be able to hide behind human rights laws to avoid deportation" (Guardian, 9 Feb 2017).

Some of the assumptions about British citizenship informing denationalization are here laid bare. First, the true "home" of these men is considered to be their origin country (nothwithstanding that at least one of the men had lived in the UK for over forty years). Formal citizenship apparently does not make one British if one is "foreign born". Second, Danczuk asserts the principle that "foreign born criminals" should not be able to hide behind human rights. Yet these men were facing deportation because they were dual nationals, not foreign 
born (naturalized) citizens. The 2006 Act supposedly applies to all dual nationals irrespective of how they acquired citizenship.

Danczuk is only one politician, and not even a member of the government. But his understanding of the principles informing denationalization seems consistent with the way the power has recently been used. Almost all who have lost citizenship under the 2006 Act have been naturalized citizens. Danczuk does not of course say the power is appropriate only for some sections of the naturalized citizen population. Yet, in practice, denationalization has been used almost exclusively on citizens originally from Muslim-majority countries, even when terrorism is not a factor.

\section{Conclusion}

In this article, I have tried to shine a light on denationalization's history. The power has typically been wielded against citizens from unpopular racial, ethnic, national and gender groups. This association between denationalization and discrimination led the power to virtually disappear in the post-War period. However, over the last two decades denationalization has re-emerged. Contemporary denationalization power is in principle more constrained. Formal gender discrimination has been expunged, and use of the power is restricted by statelessness norms. In many countries the naturalised are no longer formally picked out as contingent citizens.

Yet, as I have shown with the UK, contemporary denationalization has not truly shaken off this discriminatory past. In law, the focus of denationalization on dual nationals creates a minority holding an inferior form of citizenship. In terms of practical enforcement, denationalization is effectively reserved for naturalised citizens from Muslim-majority countries. It seems that the imaginative leap required to justify turning a citizen into an alien still requires that the 
individual in question be part of a group already viewed as less than full citizens. In both its past and present incarnations, denationalization has not simply made foreigners, it has served as a tracer for groups who, citizenship notwithstanding, are considered foreign.

\section{References}

Agamben, G. 2015.'We Refugees', Symposium 49, no. 2, pp. 114-119

Ahmed and Others. 2017. Immigration Appeal Tribunal Decision (UKUT 118), 31 March

Alienikoff, A. 1986, 'Theories of Loss of Citizenship', Michigan Law Review 84, no. 7: pp. $1471-1503$

Arendt, H. 1951. The Origins of Totalitarianism, London: Andre Deutsch

Barry, C., and L. Ferracioli. 2015. "Can Withdrawing Citizenship Be Justified?." Political Studies, Vol. 64. 1055-1070.

Carens, J. H. 2008. "Live-in Domestics, Seasonal Workers, and Others Hard to Locate on the Map of Democracy." Journal of political philosophy 16, no. 4: 419-445.

Choudhury, T. 2017. “The Radicalisation of Citizenship Deprivation”. Critical Social Policy, 37(2), 225-244.

Cott, N.F. 1998. 'Marriage and Women's Citizenship in the United States: 1880-1934', The American Historical Review 103, no. 5, December 1998: pp. 1440-1474.

CBC News Online. 2015. New citizenship rules target fraud, foreign terrorism, 25 September. Online at: http://www.cbc.ca/news/politics/new-citizenship-rules-target-fraudforeign-terrorism-1.2525404 
Dauvergne, C. 2019. "What We Learn About Human Rights by Gendering Islamophobia", Journal of Ethnic and Migration Studies, (this issue).

Ellermann, A. "Discriminations in Migration and Citizenship", Journal of Ethnic and Migration Studies (this issue.)

The Express. 2017. "The list of Britain's towns and cities shamed by Asian grooming gangs", 10 August .Online at: http://www.express.co.uk/news/uk/839509/Britain-towns-cities-asiangrooming-gangs-Newcastle-Rochdale-Rotherham

Gibney, M. J. 2013a. “A Very Transcendental Power': Denaturalisation and the Liberalisation of Citizenship in the United Kingdom'. Political Studies, 61(3), 637-655.

Gibney, M. J. 2013b. 'Should citizenship be conditional? The ethics of denationalization'. The Journal of Politics, 75(3), 646-658

The Guardian. 2017., "Members of the Rochdale Grooming Gang Face Deportation to Pakistan", 9 February. Online at: https://www.theguardian.com/uknews/2017/feb/09/members-of-rochdale-grooming-gang-face-deportation-to-pakistan House of Commons Briefing Paper. 2017. Deprivation of British citizenship and Withdrawal of Passport Facilities. Number 06820, 9 June, London.

Husbands, C. T. 2007. "German Academics in British Universities during the First World War: The Case of Karl Wichmann." German Life and Letters 60(4), pp. 493-517.

King, D. 2009. Making Americans: Immigration, Race, and the Origins of the Diverse Democracy. Cambridge: Harvard University Press.

Joppke, C. 2010. Citizenship and Immigration, Cambridge: Polity 
Lenard, P. T. 2016. Democracies and the power to revoke citizenship. Ethics \& International Affairs, 30(1), 73-91.

Lenard, P. T. 2018. "Democratic Citizenship and Denationalization." American Political Science Review 112, no. 1: 99-111.

Macklin, A., \& Baubock, R. (2015). The Return of Banishment, Florence: EUI Working Papers.

Macklin. A. 2015. 'Introduction' in Macklin, A. and Baubock, R. eds., The Return of Banishment, Florence: EUI Working Papers.

Mantu, S. 2015. Contingent Citizenship: The Law and Practice of Citizenship Deprivation in International, European and National Perspectives. Brill.

Martin D. 2002. 'The Development and Implementation of Nazi Denaturalization and Confiscation Policy up to the Eleventh Decree to the Reich Citizenship Law', Holocaust and Genocide Studies 16 pp. 217-242

Miller, D. 2016. 'Democracy, Exile, and Revocation', Ethics \& International Affairs, 30, 2 , 265-270.

Norris, M. 2016a. “A Far-Right Terrorist Murdered Jo Cox. So When is the Cobra Meeting?” New Statesman, 24 November 2016. Online at:

www.newstatesman.com/politics/staggers/2016/11/far-right-terrorist-murdered-jo-cox-sowhen-cobra-meeting

Norris, M. 2016b. Contesting Identity and Preventing Belonging?, Ph.D. Thesis, London School of Economics.

New York Times. 1918. "Loss of Citizenship for his War Views”, May 14. 
New York Times. 2016. “Trump Calls for Revoking Flag Burners' Citizenship. Court Rulings Forbid It", November 29.

Ngai, M. M. 2004. Impossible subjects: Illegal Aliens and the Making of Modern America. Princeton: Princeton University Press.

Nicholls, G. 2007. Deported: A history of forced departures from Australia. Sydney: UNSW Press.

Roche, J.P. 1950. 'The Loss of American Nationality. The Development of Statutory Expatriation', University of Pennsylvania Law Review 99, no. 1: pp. 25-71.

Smith, R. M. 1999. Civic ideals: Conflicting Visions of Citizenship in US History. New Haven: Yale University Press.

Spierenburg, Pieter. 1997. “The Body and the State: Early Modern Europe’. The Oxford History of the Prison, New York: Oxford University Press.

Spiro, P. J. 2010. Dual Citizenship as Human Right. International Journal of Constitutional Law, 8(1), pp. 111-130.

Spiro, P. J. 2011. 'A New International Law of Citizenship', American Journal of International Law 105, no. 4: pp. 694-746 
